\title{
Hair Root Activation by Anagen Grow- A Herbal Hair Growth Serum
}

\author{
Aruna V*, Amruthavalli GV and Gayathri R \\ Department of Research \& Development, Dr. JRK's Research \& Pharmaceuticals Pvt. Ltd, India
}

Submission: January 28, 2019; Published: February 05, 2019

*Corresponding author: Aruna V, Department of Research \& Development, Dr. JRK's Research \& Pharmaceuticals Pvt. Ltd, Chennai, India

Abstract

Aim: Aim of the present study is to evaluate the hair growth promoting effect of Anagen grow, a poly herbal hair serum formulated with the following herbs Murraya koenigii, Lawsonia alba, Indigofera tinctoria, Hibiscus rosa sinensis, Eclipta prostrata.

Method: Hair growth elongation assay was performed by culturing the hair root in tissue culture media with various herbal extracts. Hair growth elongation was subsequently photographed.

Result: Anagen grow has affected the hair growth elongation and similarly many herbs also showed the above property. The spectrogram of different herbs of 'anagen grow' showed similarity with the profile and absorbance value of EGCG. In the light of the above finding anagen grow inhibiting alpha reductase enzyme similar to EGCG is postulated.

Conclusion: Hair growth elongation property and the possible alpha reductase enzyme inhibition makes Anagen grow a safe and effective hair growth promoting serum and alternative to finasteride. The Minoxidil users also would benefit greatly from Anagen grow both for promoting hair growth and as well as to minimize scalp dryness due to minoxidil.

Keywords: Hair serum; Epi Gallo Catechin 3-Gallate (EGCG); Androgenic alopecia; Minoxidil; Anagen grow

\section{Introduction}

Hair is considered to be the most important organ in the mammalian system that defines the appearance, gender difference, offers protection from extreme temperature and plays a role in self- defense [1,2].

In human being, hair in the scalp defines high self- esteem and confidence. During aging, hair loss is quite natural and common however it causes great concern to people. Due to several lifestyle related changes such as stress, anxiety, consumption of junk foods, use of various hair styling/coloring procedures etc., the younger generations have started to suffer from serious hair loss problem $[3,4]$. In most instances the hair loss is not transient, but it results in alopecia. Due to severe anxiety and stress, those who suffer from hair loss seek several remedies starting from folklore to traditional to spiritual healing to use of minoxidil and finaestride. Hair root activation is necessary to increase hair growth and to prevent hair loss [5].

Several scientific attempts have been made to prevent hair loss and increase hair growth, but nothing has offered any great promise. One of the reasons for the hair loss is due to alpha reductase enzyme which converts testosterone to Dihydrotestosterone (DHT). The hair follicles have receptors of DHT and as a result the dermal papillae cells shrink due to the binding of DHT which cause atrophy of the stem cell- Dermal papillae [6].

Minoxidil and finasteride are used for the treatment of hair loss but due severe side effects along with possible treatment failure a definite solution for hair loss remains elusive and evasive $[7,8]$.

Certain plants like amla, green tea etc., have Epi Gallo Catechin 3-Gallate (EGCG). EGCG is scientifically proven to have activity against alpha reductase enzyme and thus offer great relief to alopecia. Further EGCG is water soluble and would get absorbed well through scalp epidermis $[9,10]$.

We in the present paper have employed fractionation techniques to obtain high concentration epigallin and catechin from amla and other herbs and have studied their effect on hair epidermis. Details are presented in the paper. 


\section{Materials and methods}

\section{Media- RPMI 1640}

RPMI 1640 was procured from HI media and was used. Similarly, Streptomycin and amphotericin were used to arrest the bacterial and fungal growth.

\section{Extraction and confirmation of EGCG}

Fresh amla was collected, washed, grated, and then dissolved in water for two hours. After two hours it was filtered, and the filtrate was used. The filtrate was treated with chloroform thrice to remove pigments and non-polar constituents. The filtrate was then read through spectrophotometer and EGCG was read between 260 to $270 \mathrm{~nm}$. The likely concentration of EGCG was then calculated from a standard curve of EGCG [11].

The following herbs such as Murraya koenigii, Lawsonia alba, Indigofera tinctoria, Hibiscus rosa sinensis, Eclipta prostrata are reported to have strong hair growth promoting activity were also used for the study. $1 \%$ aqueous extract of all the herb were prepared and then used. In brief $1 \mathrm{gm}$ of the above herb was dispensed in $100 \mathrm{ml}$ of water and was boiled for 10 minutes. After 10 minutes of boiling it was allowed to cool and then filtered and the filtrate was readjusted to $100 \mathrm{ml}$ with the help of water. The above procedure was done for all the herbs. The yield details of the above herbs are presented in the (Table 1).

Table 1:

\begin{tabular}{|c|c|}
\hline Name of the Herb & Extractive Value in \% \\
\hline Murraya koenigii & 32 \\
\hline Lawsonia alba & 25 \\
\hline Indigofera tinctoria & 22 \\
\hline Hibiscus rosa sinensis & 15 \\
\hline Eclipta prostrata & 20 \\
\hline Phyllanthus emblica & 50 \\
\hline
\end{tabular}

\section{Epilation of anagen hair}

Healthy willing volunteers were identified. The healthy willing volunteers were identified based on unit trichogram assay. In brief the ratio of anagen hair and telogen hair was 7:3. The scalp was cleaned thoroughly with ethanol. With the help of a sterile forceps' hair samples were pulled and the hair root along with sheath was separated and used. The anagen hair collected were gently washed in distilled water and inoculated carefully into the tissue culture media (RPMI 1640 with antibiotics). The tissue culture media supplemented with EGCG at varying concentrations in triplicate and was maintained. The hair was taken out from the media after 7 days and examined under microscope to check the cell viability and rate of multiplication by haematoxylin and eosin staining [12].

\section{Results}

Phyllanthus emblica, Hibiscus rosa sinensis and Eclipta prostrata significantly affected the hair root elongation by 7 th day. The hair root enlargement, increased cell viability and growth and sebaceous activity around the hair root were observed in the hair treated with above herbal extracts. The anagen grow treated hair also showed hair root elongation, cell viability and cell growth along with distinct sebaceous gland activity (Figure $1 \& 2$, Table 2).

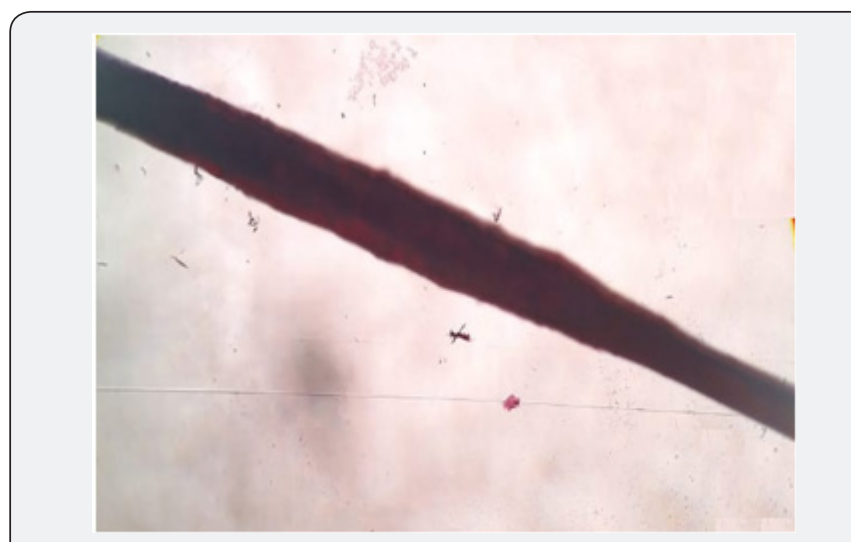

Figure 1: Control, No hair shaft enlargement, No cell multiplication, no sebaceous gland activity.

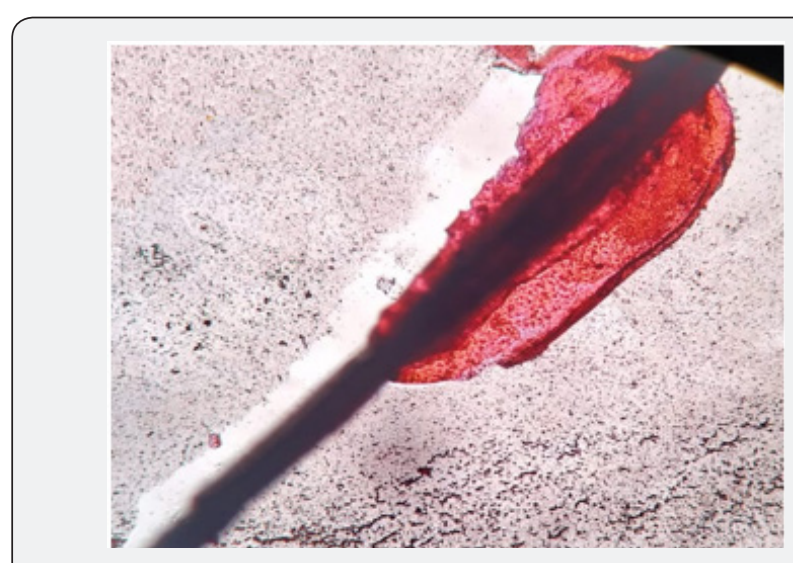

Figure 2: Anagen treatment- Day 7.

Hair shaft enlargement, increased cell. multiplication and sebaceous gland activity.

Table 2: Hair growth elongation and sebaceous gland activity in RPMI 1640 treated with herbal extracts.

\begin{tabular}{|c|c|c|}
\hline \multirow{2}{*}{ Name of the Herbs } & \multicolumn{2}{|c|}{ Hair Growth Elongation/ Day 7 } \\
\cline { 2 - 3 } & $\begin{array}{c}\text { Cell Viability \& } \\
\text { Growth }\end{array}$ & $\begin{array}{c}\text { Sebaceous Gland } \\
\text { Activity }\end{array}$ \\
\hline Phyllanthus emblica & ++ & ++ \\
Murraya koenigii, & ++ & + \\
Lawsonia alba, & - & - \\
Indigofera tinctoria, & - & - \\
Hibiscus rosa sinensis, & +++ & +++ \\
Eclipta prostrata & +++ & +++ \\
Anagen grow & +++ & +++ \\
Control- untreated & - & - \\
EGCG & ++ & +++ \\
\hline
\end{tabular}




\section{Discussion}

In vitro hair growth elongation has been used widely for screening the efficacy of hair growth promoting agents. The above method is cost effective, rapid and reliable to predict the activity of the herbs. In our present study Phyllanthus emblica, Hibiscus rosa sinensis and Eclipta prostrata have shown significant activity in enhancing the width of the hair, the stem cell activity of hair root and the activity of sebaceous gland. Similarly, Anagen grow also showed the above effect. Several studies have shown that Phyllanthus emblica, Hibiscus rosa sinensis and Eclipta prostrata possess strong hair growth promoting property [13-15].

Our earlier studies have shown that the above herbs promote hair growth specific protein synthesis when tested by mRNA assay using shh (Sonic Hedge Hog) [16]. On a cursory understanding of the possible active constituents that may be responsible for the hair growth promotion led us to the presumption that all the herbs have a chemical constituent (s) with an absorbance value closer to the absorbance value of EGCG by spectrophotometer.

EGCG has been proven to inhibit alpha reductase enzyme [10]. The hair growth promoting property what we have seen for Phyllanthus emblica, Hibiscus rosa sinensis and Eclipta prostrata along with the active constituent (s) identical to that of EGCG at the absorbance level suggests that the above plants either may possess some bio-similar molecules or some other bio-active constituent (s) other than EGCG also may have strong hair growth promoting property.

To arrest the hair loss, hair root activation and enhancing sebaceous gland activity are necessary. Considering the possible alpha-reductase inhibition effect of EGCG and bio-similar molecules of the three plants Phyllanthus emblica, Hibiscus rosa sinensis and Eclipta prostrata clearly indicates the possibility of these plants having alpha-reductase inhibition activity. Alphareductase inhibition is necessary for preventing androgenic alopecia. Finasteride is used for treating androgenic alopecia. Finasteride is known to produce severe side effects and hence its use is highly limited [7].

Considering the broad-spectrum activity of Phyllanthus emblica, Hibiscus rosa sinensis and Eclipta prostrata in increasing hair growth specific protein as revealed by our earlier mRNAbased study and the findings of the present study suggests that Anagen grow may effectively address the problem of hair loss and androgenic alopecia.

The plants used in the formulation of Anagen grow are extremely safe, been in use for centuries and are proven by several studies, therefore Anagen grow will be effective and safe than finasteride.

EGCG has greater dermal absorption than through oral route. The bio-similar molecules present in Anagen grow is in all likelihood will have greater dermal absorption. Therefore, Anagen grow may offer significant hair growth promotion as the Anagen grow is prepared in serum form.
The scientific findings and the formulation nuances make the Anagen grow an effective solution for hair loss problems and a safe alternative to finasteride. Anagen grow also provides significant moisturization effect to the scalp and hence it can be also used by those who use minoxidil as minoxidil known to cause severe scalp dryness. Further the mechanism action of minoxidil has very limited role in hair growth and when it combines with Anagen grow, a total and permanent solution to the problem of hair loss and androgenic alopecia is possible. Nevertheless, further intense study is required.

\section{Conclusion}

The study finding clearly shows that herbal remedy can give enormous promise to the problem of hair loss. Herbs are likely to possess multi-various mechanism of action such as hair growth elongation, hair stem cell activation, alpha-reductase inhibition, angiogenesis etc. Anagen grow serum is scientifically proven to have hair growth promoting benefit.

\section{References}

1. Joey E LaiCheong, John A McGrath (2009) Structure and function of skin, hair and nails. Medicine 37(5): 223-226

2. Swift JA (1999) The mechanics of fracture of human hair. Int J Cosmet Sci 21(4): 227-239.

3. Bolduc C, Shapiro J (2001) J Hair care products: Waving, straightening, conditioning, and coloring. Clin Dermatol 19(4): 431-436.

4. Robbins CR (2013) Chemical and Physical Behavior of Human Hair. $4^{\text {th }}$ edn, New York, USA.

5. Flores A, Schell J, Krall AS, Jelinek D, Miranda M, et al. (2017) Lactate dehydrogenase activity drives hair follicle stem cell activation. Nature Cell Biology 19(9): 1017-1026.

6. Urysiak-Czubatka I, Kmieć ML, Broniarczyk-Dyła G (2014) Assessment of the usefulness of dihydrotestosterone in the diagnostics of patients with androgenetic alopecia. Postepy Dermatol Alergol 31(4): 207-215.

7. Chandrashekar BS, Nandhini T, Vasanth V, Sriram R, Navale S (2015) Topical minoxidil fortified with finasteride: An account of maintenance of hair density after replacing oral finasteride. Indian Dermatol Online J 6(1): 17-20.

8. Leyden J, Dunlap F, Miller B, Winters P, Lebwohl M, et al. (1999) Finasteride in the treatment of men with frontal male pattern hair loss. J Am Acad Dermatol 40(6): 930-937.

9. Bhavesh C Variya, Anita K Bakrania, Snehal S, Patel (2016) Emblica officinalis (Amla): A review for its phytochemistry, ethnomedicinal uses and medicinal potentials with respect to molecular mechanisms. Pharmacological Research 111: 180-200.

10. OS Kwon, JH Han, HG Yoo, JH Chung, KH Cho, et al. (2007) Human hair growth enhancement in vitro by green tea epigallocatechin-3-gallate (EGCG). Phytomedicine 14(7-8): 551-555.

11. Snitsarev V, Young MN, Miller RM, Rotella DP (2013) The spectral properties of (-)-epigallocatechin 3-0-gallate (EGCG) fluorescence in different solvents: dependence on solvent polarity. PLoS One 8(11): e79834.

12. Nilforoushzadeh M, Rahimi Jameh E, Jaffary F, et al. (2017) Hair Follicle Generation by Injections of Adult Human Follicular Epithelial and Dermal Papilla Cells into Nude Mice. Cell J 19(2): 259-268.

13. Luanpitpong S, Nimmannit U, Pongrakhananon V, Chanvorachote Emblica P (2011) (Phyllanthus emblica Linn) Fruit Extract Promotes Proliferation in Dermal Papilla Cells of Human Hair Follicle. Research Journal of Medicinal Plant 5(1): 95-100. 
14. Swanand S Pathak, Monil Yogesh Neena (2018) Gala Evaluation of Hair Growth Potentiation Activity of Hibiscus Rosa Sinensis In Disturbed Circadian Rhythm. International Journal of Current Research 10(3): 67151-67155.

15. Datta K, Singh AT, Mukherjee A, Bhat B, Ramesh B, et al. (2009) Eclipta alba extract with potential for hair growth promoting activity. J Ethnopharmacol 124(3): 450-456.
16. Krishnamoorthy JR, Ranganathan S, Gokulshankar S, Ranjith MS (2003) A Novel Herbal Formulation Enhancing Protein Synthesis Specific for Hair Growth- A Northern Blotting Assay". Journal of Applied Cosmetology 21: 167-175.

\section{Your next submission with Juniper Publishers} will reach you the below assets

- Quality Editorial service

- Swift Peer Review

- Reprints availability

- E-prints Service

- Manuscript Podcast for convenient understanding

- Global attainment for your research

- Manuscript accessibility in different formats

( Pdf, E-pub, Full Text, Audio)

- Unceasing customer service

Track the below URL for one-step submission https://juniperpublishers.com/online-submission.php 